\title{
SPECIFIC CHARACTERISTICS OF HYDRODYNAMIC TRAUMA AND ITS IDENTIFICATION
}

\author{
T.K. Osipenkova ${ }^{1}$, V.V. Rozanov ${ }^{2}$, I.V. Matveychuk ${ }^{3}$, S.A. Shutyeev ${ }^{4}$
}

\begin{abstract}
The paper discusses the problems relating to an examination of injuries from hydrodynamic jets of high pressure. Evaluations of the depth of the field of the destruction area when exposed to a jet have been obtained, the data of morphological studies are adduced. Thus, the necessary is laid basis for performing expert assessments and recommendations aimed at an elaboration of practical approaches to a systematic identification of hydrodynamic lesions of tissues and organs.
\end{abstract}

Key words: forensic medical examination, hydrodynamic injury, identification.

${ }^{1}$ FERC HM RF,

${ }^{2}$ FSBI SIMC «Basis»,

${ }^{3}$ BMT VILAR (Moscow),

${ }^{4}$ M.V.Lomonosov MSU (Moscow)

Рецензент - проф. В.Т. Бачинський

Buk. Med. Herald. - 2013. - Vol. 17, № 3 (67), part 1. - P. 119-122

Надійшла до редакції 07.06.2013 року

() Т.К. Осипенкова, В.В. Розанов, И.В. Матвейчук, С.А. Шутеев, 2013

УДК 572.788-340.982.325

Ю.И. Пиголкин, Г.В. Золотенкова

\section{ВОЗРАСТНЫЕ ИЗМЕНЕНИЯ НЕРВНОГО АППАРАТА СОСУДОВ СПИННОГО МОЗГА}

Первый Московский медицинский университет им И.М. Сеченова

\begin{abstract}
Резюме. Проведено изучение нервного аппарата сосудов спинного мозга для установления биологического возраста человека. Пиальные и внутримозговые сосудистые системы и спинного мозга человека изучались в разные периоды постнатального онтогенеза (от 1 года до 90 лет). Полученные данные о возрастных изменениях нервного аппарата спинномозговых артерий
\end{abstract}

Введение. Ежегодный рост числа жертв техногенных аварий, локальных вооруженных конфликтов, неорганизованной миграции населения обуславливает актуальность проблемы идентификации личности. При судебно-медицинской идентификации личности в условиях фрагментации тел, значительных повреждений трупов за счет воздействий физических факторов, поздних трупных изменений, роль общих признаков (пол, возраст, рост и т.д.), позволяющих установить принадлежность идентифицируемого к определенной группе, значительно возрастает $[4,6]$. В настоящее время существует необходимость в расширении спектра применяемых современных методов исследования, использования как можно большего количества органов и систем для более точного и полного анализа, в первую очередь, биологического возраста человека, с последующим созданием принципиального алгоритма исследования [4-6].

Цель исследования. Изучить закономерности возрастных изменений нервного аппарата сосудов спинного мозга для разработки объективных критериев судебно-медицинской диагностики биологического возраста.

(C) Ю.И. Пиголкин, Г.В. Золотенкова, 2013 122 могут быть использованы для решения вопросов судебно-медицинской практики.

Ключевые слова: идентификация личности, определение возраста, внутренние органы, нервный аппарат сосудов головного и спинного мозга, морфология, морфометрия, биологический возраст.

Материал и методы. Пиальные и внутримозговые сосудистые системы спинного мозга изучены на материале, полученном при судебномедицинских вскрытиях трупов людей (190 трупов мужского пола в возрасте от 1 года до 90 лет), погибших преимущественно от травм. При распределении материала по возрастным группам мы учитывали периодизацию, принятую на 7-ой Всероссийской научной конференции по проблемам возрастной морфологии, физиологии и биохимии (М., изд. АПН СССР, 1965). При исследовании были использованы гистологические методы - Кампоса, Вейгерта-Паля, окраска препаратов гематоксилин-эозином, по Ван-Гизон, Массону, 0,5 \% спиртовым раствором метиленового синего, а также с помощью инъекции сосудов водным раствором туши. Флуоресцентногистохимический метод с глиоксиловой кислотой использовали для идентификации адренергической иннервации, гистохимические методы Берта на холинацетилтрансферазу (ХАТ) и Келле на ацетилхолинэстеразу (АХЭ) для выявления холинергической иннервации, на аспартатаминотранферазу - чувствительной иннервации. Методом 
Хоупа и Винсента в нервных сетях сосудов выявляли NADPH-диафоразу - элективного маркера NO-синтазы. Наличие вазопрессина в клетках и волокнах исследовали иммунногистохимическим методом. Для изучения сосудисто-нервного аппарата были использованы просвечивающая и сканирующая электронная микроскопия. Для определения концентрации моноаминов в клетках и волокнах применялась флуоресцентная спектрофотометрия.

Результаты исследования и их обсуждение. Изучение нервного аппарата артерий спинного мозга человека позволило установить, что афферентная и эфферентная иннервация существенно меняется в процессе онтогенеза [1-3, 7]. Морфологический субстрат иннервационных связей дифференцируется в большей степени после рождения. В течение первого года жизни ребенка происходят значительные количественные и качественные преобразования афферентной иннервации кровеносных сосудов спинного мозга. В возрастном интервале от 13 до 44 лет эти показатели стабилизируются, но их значения относительно выше, чем в предыдущих возрастных группах. В 45-54 года впервые определяются инволютивные изменения афферентного нервного аппарата артерий, которые являются частным проявлением «деафферентационного феномена» [2, 3]. При этом сопутствующие сосудистые заболевания, в первую очередь, атеросклероз и гипертоническая болезнь существенно изменяют картину возрастных изменений нервных сплетений, выраженность которых зависит от тяжести и особенно продолжительности болезней $[7,8]$. Увеличение объема холинергических нейронов, возрастание их способности синтезировать и накапливать ацетилхолин, ведущее к повышению уровня иннервированности спинномозговых сосудов отмечается в первые годы жизни. В период полового созревания (13-18 лет) концентрация адрен- и холинергических нервных волокон, уровень активности медиаторов и ферментов достигают дефинитивного состояния и практически не меняются до 45 лет. С возрастом отмечается ослабление нервных влияний на ткань, происходит редукция нервно-волокнистых структур, которой предшествуют постепенное уменьшение в них запасов трансмиттеров и ферментов. В процессе старения последовательно снижается интенсивность люминесценции нервных проводников, активность ферментов, концентрация варикозностей, что характерно для начала постмедиаторного периода онтогенеза вегетативной нервной системы $[9,10]$. Изменения ярче выражены в адренергических сплетениях, чем в холинергических. Однако изменения в нервной системе при старении нельзя сводить только к инволютивным процессам, поскольку часть нервных волокон сохраняет структуру, типичную для зрелого возраста. Число нервных волокон снижается параллельно содержанию катехоламинов и ферментов в нервных структурах сосудов [2]. Известно, что в пер- вые дни после рождения ребенка хромаффиноциты на спинномозговых сосудах встречаются довольно редко и их содержание практически не меняется до старческого возраста [2]. Концентрация тканевых базофилов прогрессивно возрастает до двух-трех лет жизни. После некоторого спада следующий пик роста приходится на 13-17 лет, что можно объяснить адаптивными процессами, обусловленными половым созреванием. С 17летнего возраста до старости концентрация тканевых базофилов практически не меняется. Концентрация меланоцитов стабилизируется в период с восьми до 55 лет. Инволютивные процессы в гранулосодержащих клетках наступают значительно позже, чем в нервном аппарате кровеносных сосудов, что имеет свой биологический смысл. Функция сосудов, постепенно теряющих к старости свои прямые нервные связи, начинает регулироваться биологически активными веществами гранулосодержащих клеток. Так, например, тканевые базофилы могут играть роль элементов гуморальной системы, а гистамин может выступать в роли медиатора. В этой связи обращает на себя внимание увеличение числа тканевых базофилов в тканях в некоторых органах у лиц пожилого возраста. На протяжении длительного периода жизни (до 45 лет) содержание биогенных моноаминов в сосудах мягкой мозговой оболочки спинного мозга, что было установлено при флюориметрическом исследовании, остается практически неизменными и лишь у лиц старческого возраста (старше 75 лет) найдены достоверные отличия в уровне биогенных моноаминов по сравнению со зрелым возрастом. Выборочные исследования, проведенные в старческом возрасте, позволили установить, что после 75 лет происходит снижение общего содержания аминов, среди которых обращает на себя внимание трехкратное сокращение уровня норадреналина. Регрессивные изменения содержания норадреналина можно объяснить выраженной деструкцией адренергического нервного аппарата кровеносных сосудов в старости. Уровень других катехоламинов снижается более плавно из-за продолжающейся деятельности гранулосодержащих клеток.

\section{Выводы}

1. Развитие нервного аппарата спинномозговых артерий человека в онтогенезе рекапитулирует в общих чертах филогенеза и включает в себя три фазы: созревания, стабилизации и инволюции.

2. Изученные параметры, отображающие возрастную динамику нервного аппарата спинномозговых артерий и могут использоваться, наряду с другими признаками, в составлении регрессионных уравнений для вычисления биологического возраста человека в судебно-медицинских целях.

Перспективы дальнейших исследований. Внедрение в экспертную практику данных о возрастных перестройках нервного аппарата спинномозговых артерий в комплексе с другими методами, для установления возрастного интервала при проведении судебно-медицинских идентификационных 
экспертиз является, на наш взгляд, перспективными. В настоящее время ведётся математическая обработка полученных данных с целью выведения расчетных формул. Применение данного метода обеспечит системный подход и учет всей информации, которая могла бы, в конечном итоге, повысить точность экспертного заключения.

\section{Литература}

1. Мотавкин П.А. Что и чем иннервировано в мозгу?/ П.А. Мотавкин // Морфология. - 2007. - № 1. C. $82-84$

2. Мотавкин П.А. Гистофизиология кровообращения в спинном мозге./ П.А. Мотавкин, Ю.И. Пиголкин, Ю.В. Каминский. - М.: Наука, 1994. - 232 с.

3. Мотавкин П.А. Иннервация мозга / П.А. Мотавкин, В.М. Черток // Тихоокеан. мед. ж. - 2008. - № 3. C. 11-23.

4. Пиголкин Ю.И. Современные методы судебномедицинской идентификации личности / Ю.И. Пиголкин // Рос. мед. вести. - 2004. - № 3. - С. 73-75.

5. Пиголкин Ю.И., Богомолова И.Н. Применение принципов доказательной медицины в качестве критериев полезности новых методов исследования в экспертной практике / Ю.И. Пиголкин, И.Н. Богомолова // Суд.мед. экспертиза. - 2003. - № 4. - С. 47-49.

6. Пиголкин Ю.И. Значение общих признаков для идентификации личности и перспективы развития методов их определения / Ю.И. Пиголкин, Д.В. Богомолов, Г.В. Золотенкова // Альм. суд. мед. - 2001. - № 2. C. 67-69.

7. Черток В.М. Эфферентная иннервация артерий мягкой оболочки мозга человека при артериальной гипертензии / В.М. Черток, А.Е. Коцюба, Е.В. Бабич // Морфология. - 2009. - Т. 135, № 3. - С. 35-41.

8. Черток В.М. Рецепторный аппарат сосудов головного мозга человека при артериальной гипертензии / В.М. Черток, А.Е. Коцюба // Ж. невропатол. и психиатрии. - 2010. - № 10. - С. 40-47.

9. Швалев В.Н. Возрастные изменения регуляторных механизмов в кардио-васкулярной системе и значение нитроксидсинтазы в норме и патологии / В.Н. Швалев // Кардиология. - 2007. - № 5. - С. 67-72.

10. Швалев В.Н. Феномен ранней возрастной инволюции симпатического отдела вегетативной нервной системы / В.Н. Швалев, Н.А. Тарский // Кардиология. 2001. - № 2. - C. 10-14.

\section{ВІКОВІ ЗМІНИ НЕРВОВОГО АПАРАТУ СУДИН СПИННОГО МОЗКУ}

\section{Ю.И. Піголкін, Г.В. Золотенкова}

Резюме. Проведено вивчення нервового апарату судин спинного мозку для встановлення біологічного віку людини. Піальні і внутрішньомозкові судинні системи й спинного мозку людини вивчалися в різні періоди постнатального онтогенезу (від 1 року до 90 років). Отримані дані про вікові зміни нервового апарату спинномозкових артерій можуть бути використані для вирішення питань судово-медичної практики.

Ключові слова: ідентифікація особистості, визначення віку, внутрішні органи, нервовий апарат судин головного та спинного мозку, морфологія, морфометрія, біологічний вік.

\section{AGE-RELATED CHANGES IN THE NERVOUS APPARATUS OF THE BLOOD VESSELS IN THE SPINAL CORD}

\section{Yu.I. Pigolkin, G.V. Zolotenkova}

Abstract. This paper was designed to study changes in the nervous apparatus of the blood vessels in the spinal cord with a view to determining the biological age of man. The pial and intramedullary vascular systems of the brain and spinal cord were examined in different periods of postnatal ontogenesis (between the age of 1 to 90 years). The data obtained on the age-related rearrangement of the nervous apparatus of the spinocerebral arterial vessels can also be used for the solution of practical problems encountered in the practical work of forensic medical experts.

Key words: personality identification, age determination, internal organs, morphology, morphometry, nervous apparatus of cerebrospinal blood vessels, biological age.

I.M. Sechenov First Moscow Medical University (Moscow)

Рецензент - проф. В.Т. Бачинський
Buk. Med. Herald. - 2013. - Vol. 17, № 3 (67), part 1. - P. 122-124

Надійшла до редакції 08.06.2013 року

(С) Ю.И. Пиголкин, Г.В. Золотенкова, 2013 